\title{
Feasibility study on the application of fly ash as a barrier material in containment systems
}

\author{
D.-I. Myoung ${ }^{1}$, G.-H. Lee ${ }^{1}$, S.-H. Lee ${ }^{1}$, J.-B. Park ${ }^{1} \&$ H.-S. Kim ${ }^{2}$ \\ ${ }^{1}$ School of Civil, Urban \& Geosystem Engineering, \\ Seoul National University, Seoul, South Korea \\ ${ }^{2}$ School of Electrical and Electronics Engineering, \\ Chung Ang University, Seoul, South Korea
}

\begin{abstract}
In this study, fly ash was employed as a potential alternative to the bentonite in contaminant barrier against cationic heavy metal, and its feasibility was estimated. Cd sorption tests were performed with soil mixtures having different fly ash/soil mixing ratios (100:0, 80:20, 60:40, 40:60, 0:100), and soil/bentonite mixture (95:5) as a control material. Their hydraulic conductivities were measured in flexible-wall permeameter, then hydraulic conductivity tests were repeated by changing the permeant liquids from tap water to $\mathrm{Cd}^{2+}$-containing solution. Finally, Cd-breakthrough from each specimen was observed for $500 \mathrm{hrs}$ to compare the effectiveness of each specimen in contaminant retardation. Test results showed fly ash had a sufficient retardation capacity against contaminants although it had little effect on the reduction of hydraulic conductivity.

Keywords: contaminant barrier, hydraulic conductivity, fly ash, flexible wall permeameter test, breakthrough.
\end{abstract}

\section{Introduction}

The amount of fly ash produced from thermal power plants has increased in every year as industrialization proceeds, and most of its disposal depends on landfilling. In recent years, various efforts for recycling fly ash have been made, and fly ash showed promising results in contaminant sorption, soil improvement, neutralization of acidic waste water. Especially, Edil et al. (1992) suggested that fly ash could be possibly applied in containment barrier for its fine particle size. Previous containment system has prevented the contaminant transport with its 
low hydraulic conductivity (below $1 \times 10^{-7} \mathrm{~cm} / \mathrm{sec}$ ) established by bentonite contents in it. However, the cation-dissolved ground water could increase the hydraulic conductivity of bentonite-containing barrier by changing the thickness of the diffused double layer of clay. And small contents of bentonite less than $5 \%$ might cause the un-homogeneity in the hydraulic conductivity through the depth of barrier. Moreover, the material cost for bentonite is high. In this study the applicability of fly ash as a barrier material in containment system was estimated. Firstly, the sorption capacities of soil mixtures having different soil/fly ash mixing ratio were estimated. Then, each mixture's hydraulic conductivity tests were measured with flexible wall permeameter. And the hydraulic conductivity tests were repeated by changing the permeant liquid from tap water to $\mathrm{Cd}^{2+}$ solution. Finally $\mathrm{Cd}$-breakthrough from each specimen was observed to compare the effectiveness.

\section{Experimental section}

\subsection{Materials}

Fly ash used in this study was obtained from Tae-an thermal power plant in Korea. The chemical composition of the material is given in Table 1.

Table 1: The predominant chemical constituents in fly ash.

\begin{tabular}{|l|l|l|l|l|l|l|l|l|l|l|l|}
\hline $\mathrm{SiO}_{2}$ & $\mathrm{Al}_{2} \mathrm{O}_{3}$ & $\mathrm{TiO}_{2}$ & $\mathrm{Fe}_{2} \mathrm{O}_{3}$ & $\mathrm{MgO}$ & $\mathrm{CaO}$ & $\mathrm{Na}_{2} \mathrm{O}$ & $\mathrm{K}_{2} \mathrm{O}$ & $\mathrm{MnO}$ & $\mathrm{P}_{2} \mathrm{O}_{5}$ & LoI & total \\
\hline 51.88 & 23.37 & 0.89 & 8.68 & 1.55 & 4.46 & 0.59 & 1.13 & 0.06 & 0.8 & 5.74 & 99.2 \\
\hline
\end{tabular}

Fly ash was primarily composed of silica, alumina, and iron. Calcium responsible for pozzolanic reaction was in low percentage. Soil used in this study was weathered granite soil which is commonly found in Korea. The soil was classified as poorly graded sand (SP) based on the Unified Soil Classification System (See Figure 1), and soil passing the U.S. Standard No.4 sieve is used in this study. The physical properties of the soil are given in Table 2 .

The physical properties of the sodium bentonite used in this experiment are given in Table 3 .

Table 2: $\quad$ The physical properties of the weathered soil.

\begin{tabular}{|l|c|}
\hline & Weathered soil \\
\hline Specific gravity & 2.61 \\
\hline Coefficient of gradation & 0.88 \\
\hline Uniformity gradation & 11.8 \\
\hline USCS & SP \\
\hline Percentage passing sieve No.200 & $8.2 \%$ \\
\hline
\end{tabular}




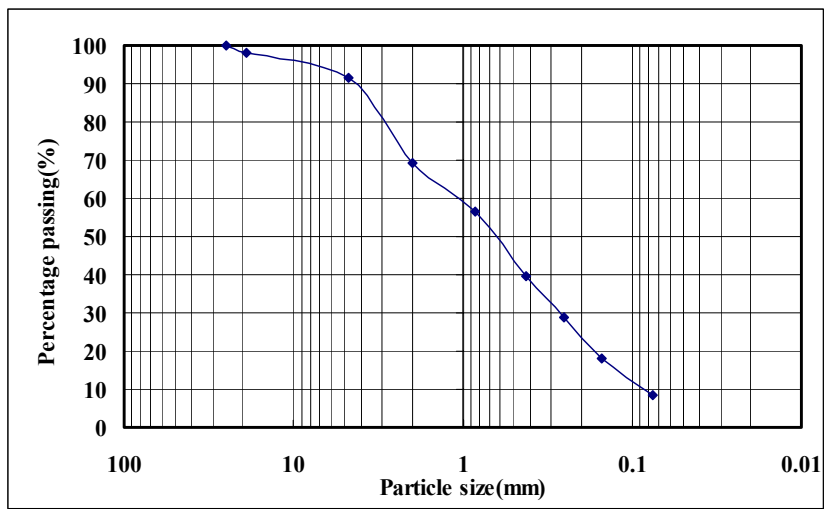

Figure 1: $\quad$ Particle size distribution of the weathered soil.

Table 3: $\quad$ Physical properties of the sodium bentonite.

\begin{tabular}{|l|c|}
\hline & Bentonite \\
\hline Specific gravity & 2.65 \\
\hline Liquid (\%) & 393 \\
\hline Plasticity Index $(\%)$ & 351 \\
\hline Specific surface area $\left(\mathrm{m}^{2} / \mathrm{g}\right)$ & 42 \\
\hline
\end{tabular}

\subsection{Experiment procedure}

\subsubsection{Sorption test}

$\mathrm{Cd}$ sorption tests were performed with materials having different fly ash/soil mixing ratio $(100: 0,80: 20,60: 40,40: 60,0: 100)$, and soil/bentonite mixture $(95: 5)$ as control material. Three grams of materials were contained in $33 \mathrm{ml}$ vial with $30 \mathrm{ml} \mathrm{Cd}^{2+}$ solution of which initial concentration was ranged in 20-5120 ppm. Then the tubes were shaken for $24 \mathrm{hrs}$, and solution was separated from solid phase by centrifuge. And residual $\mathrm{Cd}$ concentration was analyzed with atomic absorption spectrophotometer (AAS).

\subsubsection{Hydraulic conductivity test}

The specimens were molded on the wet side of optimum moisture contents with the materials used in sorption tests. And hydraulic conductivity tests were performed for the specimens using flexible wall permeameter. Firstly, tap water was used as the permeant liquid. The applied pressure for confining specimens in the cell and injecting solution through the specimens were 10psi and 3psi, respectively. No backpressure was applied. And to confirm the effect of dissolved cations on the hydraulic conductivity of specimens, tests were repeated by changing the permeant liquids from tap water to $\mathrm{Cd}^{2+}$ solution (30ppm). 


\subsubsection{Cd breakthrough analysis}

All effluent samples from the specimens were collected in vial. And then the Cdconcentration at the effluent was analyzed with AAS to compare the effectiveness of each specimen in contaminant retardation.

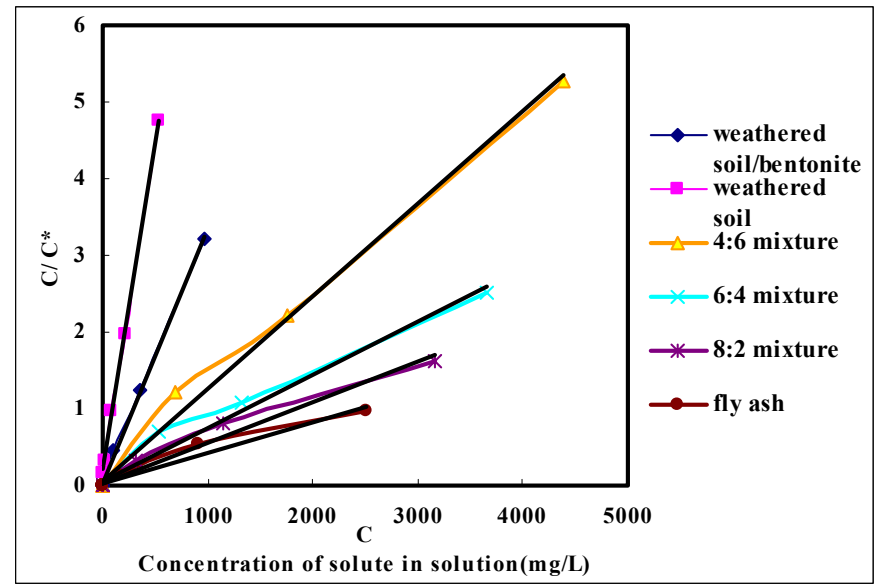

Figure 2: $\quad$ Linear Langmuir sorption isotherm with $\mathrm{C} / \mathrm{C}^{*}$ versus $\mathrm{C}$.

\section{Results and discussion}

\subsection{Sorption test}

The isotherm data in Figure 2 were described by the linear form of the Langmuir equation:

$$
\frac{C}{C^{*}}=\frac{1}{\alpha \beta}+\frac{C}{\beta}
$$

where $\alpha=$ an absorption constant related to the binding energy $(\mathrm{L} / \mathrm{mg}), \beta=$ the maximum amount of solute that can be absorbed by the solid( $\mathrm{mg} / \mathrm{kg})$.

Distribution coefficient of $\mathrm{K}_{\mathrm{d}}$ was calculated by:

$$
\frac{\alpha \beta}{(1+\alpha C)^{2}}=K_{d}
$$

$\mathrm{K}_{\mathrm{d}}$ values of each specimen were summarized in Table 4.

As shown in Table $4, \mathrm{~K}_{\mathrm{d}}$ values of fly ash mixtures were 7-17 times higher than those of without fly ash. $K_{d}$ value increased with increasing fly ash contents in mixture. From this result, it might be expected that fly ash could effectively attenuate contaminant transport for its high sorption capacity. 
Table 4: $\quad$ The $\mathrm{K}_{\mathrm{d}}$ values of each specimen.

\begin{tabular}{|l|c|}
\hline Specimen & $\mathrm{K}_{\mathrm{d}}(\mu \mathrm{g} / \mathrm{g})$ \\
\hline Weathered soil & 0.92 \\
\hline Weathered soil/bentonite $(95: 5)$ & 1.83 \\
\hline Fly ash/weathered soil $(40: 60)$ & 6.63 \\
\hline Fly ash/weathered soil $(60: 40)$ & 9.08 \\
\hline Fly ash/weathered soil $(80: 20)$ & 13.54 \\
\hline Fly ash & 16.19 \\
\hline
\end{tabular}

\subsection{Hydraulic conductivity test}

Hydraulic conductivity of specimens for tap water is shown in Figure 3.

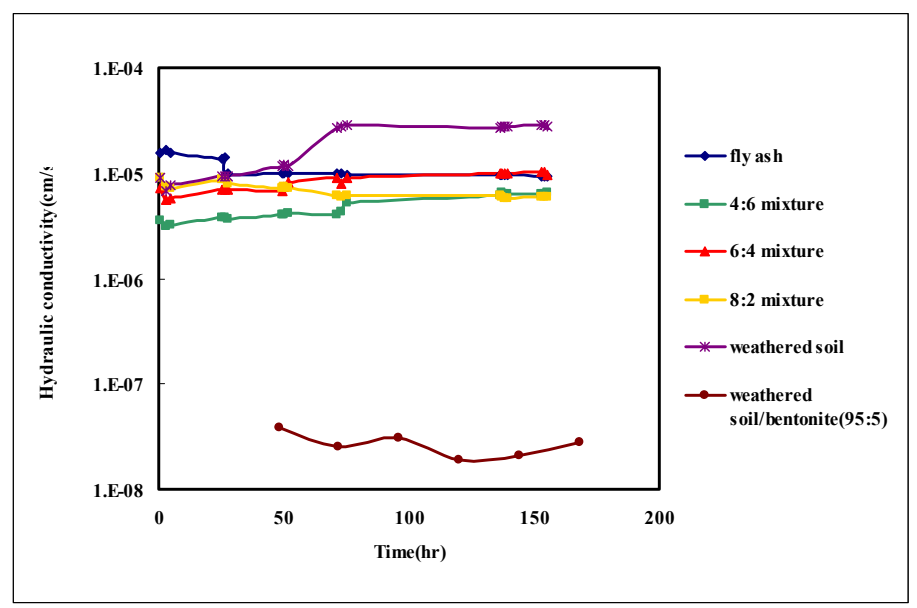

Figure 3: Hydraulic conductivity for tap water.

The fly ash mixtures showed similar hydraulic conductivity of about $10^{-5}$ $\mathrm{cm} / \mathrm{sec}$. However, the hydraulic conductivity slightly decreased in higher fly ash contents possibly due to cementation reaction. From the test result, it could be concluded that fly ash does not have significant effect on reducing hydraulic conductivity. When the permeant liquid was changed from tap water to $\mathrm{Cd}^{2+}$ solution, the results were shown in Figure 4.

Hydraulic conductivities of all specimens except for weathered soil were maintained as similar as in tap water. Especially, unlike the theoretical expectation, $\mathrm{Cd}$ effect on the hydraulic conductivity of soil/bentonite mixture was minimal. It might be possibly due to relatively short reaction time.

\subsection{Cd breakthrough analysis}

Cd-breakthrough curves from each specimen are shown in Figure 5. For weathered soil, the breakthrough was initialized at about 5hrs after injecting 
$\mathrm{Cd}^{2+}$ solution as shown Figure 5. Whereas, that of mixtures containing fly ash was not observed for total experimental period of $500 \mathrm{hrs}$, which was similar with that from soil/bentonite (95:5) mixture. The result implied that fly ash had a sufficient retardation capacity to prevent contaminant transport, although it showed little effect on the reduction of hydraulic conductivity.

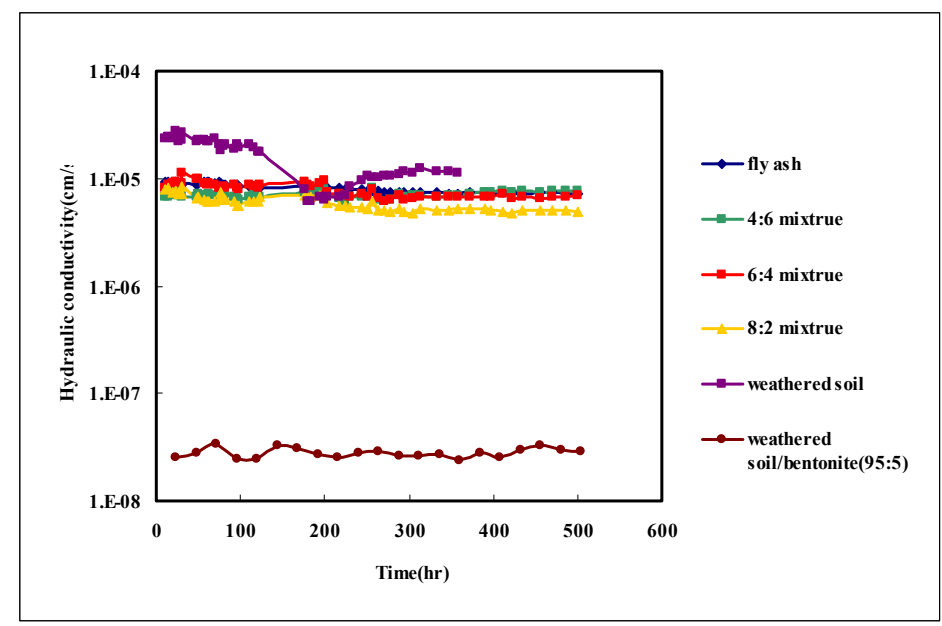

Figure 4: Hydraulic conductivity for $\mathrm{Cd}^{2+}$ solution.

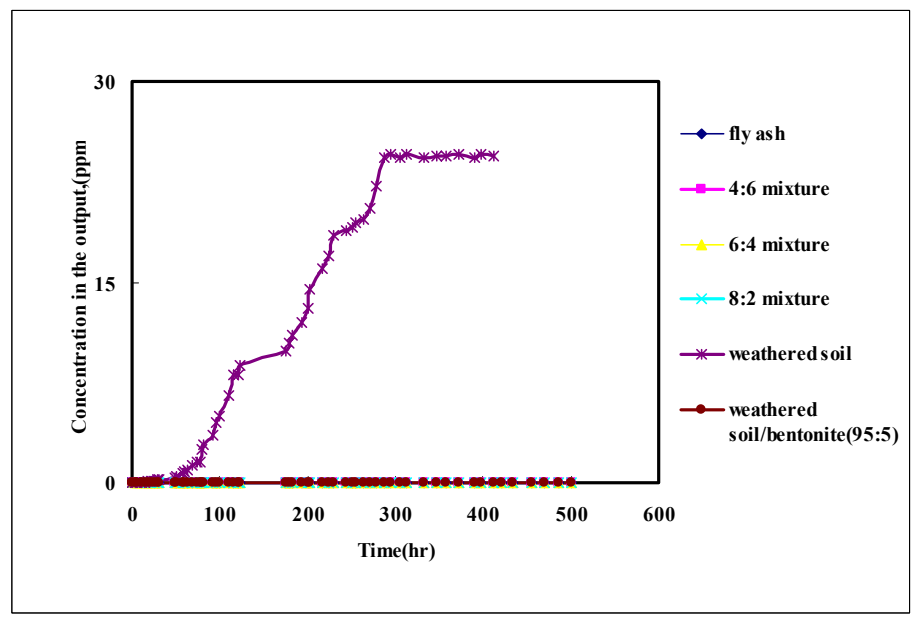

Figure 5: The concentration versus time relation of the outflow. 


\section{Conclusion}

Sorption test results showed that fly ash had the high sorption capacity for Cd. However, it was found that fly ash had little effect on reduction of hydraulic conductivity. Cd-breakthrough from fly ash mixtures was not observed even after $500 \mathrm{hrs}$, which was similar with that from soil/bentonite (95:5) mixture. With the results obtained in this study, it might be concluded that fly ash could be possibly used as suitable barrier material in containment system for its high retardation capacity and for the low material cost. However, to suggest the more reliable result, it might be necessary to compare the breakthrough curve of soil/bentonite (95:5) mixture and fly ash mixture during longer period.

\section{Acknowledgements}

This study was sponsored by Korea Electrical Engineering and Science Research Institute (R-2002-B-257) and thanks are due for the support.

\section{References}

[1] Brian G. Palmer, et al. (2000) "Liners for waste containment constructed with class F and C fly ashes", Journal of Hazardous Materials, 76, pp.193216.

[2] Bowders, J.J, et al. (1990) "permeability and leachate characteristics of stabilized class F fly ash”, Transportation Research Board Record 1288, National Research Council, Washington D.C. USA, pp.70-77.

[3] David J. D'Appolonia and Christopher R. Ryan (1979), "Soil-Bentonite slurry trench cutoffs", Journal of the Geotechnical Engineering Division, Proceedings of the American Society of Civil Engineers, Vol. 106, No. GT4, pp.399-417.

[4] Fetter (1993) "Contaminant Hydrogeology", Macmillan Publishing Company, a division of Macmillan, Inc. pp.122-125.

[5] Janice L. Ruhl et al. (1997), "Geosynthetic clay liners permeated with chemical solutions and leachates", Journal of Geotechnical and Geoenvironmental Engineering, Vol. 123, No.4 pp.369-381.

[6] Mark H. Gleason, et al. (1997) "Calcium and sodium bentonite for hydraulic containment applications", Journal of Geotechnical and Geoenvironmental Engineering, ASCE 123(5), pp.438-445.

[7] Tuncer B. Edil, et al. (1992) "Interaction of inorganic leachate with compacted pozzolanic fly ash", Journal of Geotechnical Engineering, 118(9), pp.1410-1430. 